\title{
Electrochemical Behavior and Corrosion Study of Electrodeposits of Zn and Zn-Fe-Co on Steel
}

\author{
Conceição A. M. Dutra ${ }^{*}$, Eduardo N. Codaro, Roberto Z. Nakazato
}

Departamento de Física e Química, Universidade Estadual Paulista, Campus de Guaratinguetá, Guaratinguetá, Brazil.

Email: *conmat@feg.unesp.br

Received March 21 ${ }^{\text {st }}, 2012$; revised April 25 ${ }^{\text {th }}, 2012$; accepted May $26^{\text {th }}, 2012$

\begin{abstract}
From industrialized baths, free of cyanide, the corrosion behavior of electrodeposits of zinc and zinc alloys was studied by means of electrochemical tests in aerated solution of $3.5 \%(0.6 \mathrm{M}) \mathrm{NaCl}$ at $\mathrm{pH}$ 8.2. In literature, several studies are found about zinc coatings and zinc alloys, for example, $\mathrm{Zn}-\mathrm{Ni}$ and $\mathrm{Zn}-\mathrm{Co}$, nevertheless there is little about the ternary alloy $\mathrm{Zn}-\mathrm{Fe}-\mathrm{Co}$. The Fe presence in the alloy results in a good adhesion to the substrate and allows application of these materials at higher temperatures. The electrochemical tests were carried out by obtaining open circuit potential curves with immersion time, potentiodynamic polarization curves and cyclic voltammetry. From the obtained results, the large potential differences observed between the steel and the electrodeposits showed that the last protect the substrate, acting as a sacrifice metal. The tests disclosed similar behaviors in both the current densities and the corrosion potential for electrodeposits of $\mathrm{Zn}$ and $\mathrm{Zn}-\mathrm{Fe}-\mathrm{Co}$. After chromate passivation process, a significant decrease in corrosion density was noted for $\mathrm{Zn}$ and when the system was de-aerated there was change in the cathodic process mechanism.
\end{abstract}

Keywords: Corrosion; Electrodeposition; Zn; Zn Alloy

\section{Introduction}

Zinc gives galvanic protection to steel by presenting a good accomplishment in most atmospheric conditions and also good mechanical and corrosive characteristics. In relation to electrogalvanised layers, zinc alloys have been commonly more used due to their low cost and their resistance to the corrosion process, which can triple, making them significantly more efficient [1]. Zinc electrodeposition with metals of Fe group, besides cost advantage, it is classified as anomalous [2]; these coatings present protection mechanisms by barrier associated with cathodic protection $[3,4]$.

The increasing use in the industries has caused a great progress in technology of coatings based on zinc. In recent years, particularly in automotive industry, it has increased the requirements and the demand of coatings, which are alternative to zinc and cadmium for steel protection. It has resulted in the development of zinc alloys with metals of group VIII B, such alloys present superior properties of corrosion resistance and low toxicity. Furthermore, characteristics of these coatings can be improved by post-treatment.

Chemical conversion processes with chromates are widely applied in metals passivation. Chromatization is used as a more effective inhibiting process, although the

"Corresponding author. hexavalent chromium presents very toxic effects. As a result, oxy-anions similar to chromate, such as molybdate, tungstate and vanadate, are studied as alternatives. The objective of this paper is to study the electrochemical behavior of $\mathrm{Zn}$ and $\mathrm{Zn}$-Fe-Co electrodeposits upon steel in $3.5 \% \mathrm{NaCl}$, by analyzing the addition effect of $\mathrm{CrO}_{4}^{2-}$, $\mathrm{MoO}_{4}^{2-}$ and $\mathrm{WO}_{4}^{2-} 0.05 \mathrm{M}$.

\section{Materials and Methods}

Using as substrate SAE 1010 steel plates $0.75 \mathrm{~mm}$ thick, the working electrode was prepared with pure $\mathrm{Zn}$ electrodeposits (NCZ ZINCROLYTE $191^{\circledR}$ ) and Zn-Fe-Co (NCZ ZINCROLYTE $191 \mathrm{Fe} / \mathrm{Co}^{\circledR}$ ) in commercial baths based on chlorides, cyanide-free and industrially obtained with a thickness of around $10 \mu \mathrm{m}$. During immersion of the samples, a current density from 2 to $4 \mathrm{~A} \cdot \mathrm{dm}^{-2}$ was applied with a temperature of about $25^{\circ} \mathrm{C}$. All electrodeposition procedures were obtained in a laboratory of Electronics Enthone Brazil Ltda, which are properties and trademarks of Cookson Electronics Brazil Ltda. After electrodeposition procedure, a part of the sample was passivated by chemical conversion of blue chromate (PERMAPASS $3080^{\circledR}$ ). With a potentiostat EG\&G PAR 283 support, controlled by programs Softcorr III and Power Suite, interfaced by GPIB plate to a computer for control and data processing, electrochemical tests were 
conducted in a flat corrosion cell with a capacity of 250 $\mathrm{mL}$, borosilicate glass with compartments for platinum counter electrode, working electrode and reference electrode $\mathrm{Ag} / \mathrm{AgCl}$, KClsat (+197 $\mathrm{mV}$ vs. NHE). The used electrolyte was a $3.5 \% \mathrm{NaCl}, \mathrm{pH} 8.2$, prepared with analytical grade reagent and distilled water, with and without group VIB oxy-anions presence $\left(\mathrm{CrO}_{4}^{2-}, \mathrm{MoO}_{4}^{2-}\right.$ and $\mathrm{WO}_{4}^{2-}$ ) at a concentration of $0.05 \mathrm{M}$, at $25^{\circ} \mathrm{C}$.

\section{Results and Discussion}

\subsection{Measurements of Open Circuit Potential} (Eоc)

During 600 minutes without passing any electric current, pure electrodeposits of $\mathrm{Zn}$ and $\mathrm{Zn}-\mathrm{Fe}-\mathrm{Co}$ were analyzed by using $3.5 \% \mathrm{NaCl}, \mathrm{pH} 8.2$, with and without chromate treatment and addition of oxy-anions. Compared to pure $\mathrm{Zn}$, samples of $\mathrm{Zn}-\mathrm{Fe}-\mathrm{Co}$, both for untreated and passivated, corrosion potentials remain close. When the pure $\mathrm{Zn}$ electrodeposits are treated by chromatization, it is noted that, in a general way, the potentials obtained in open-circuit are shifted to more positive values than those obtained for zinc without treatment, indicating that in chromatization procedure, it occurs stable species formation, which protect the material from a corrosive chloride attack. With oxy-anions addition to chloride, potential values variations occurred for $\mathrm{Zn}$ coating Figure 1(a). The corrosion potentials are shifted to more positive values in presence of all studied oxy-anions. This corrosion potential increase means a higher stability of the formed

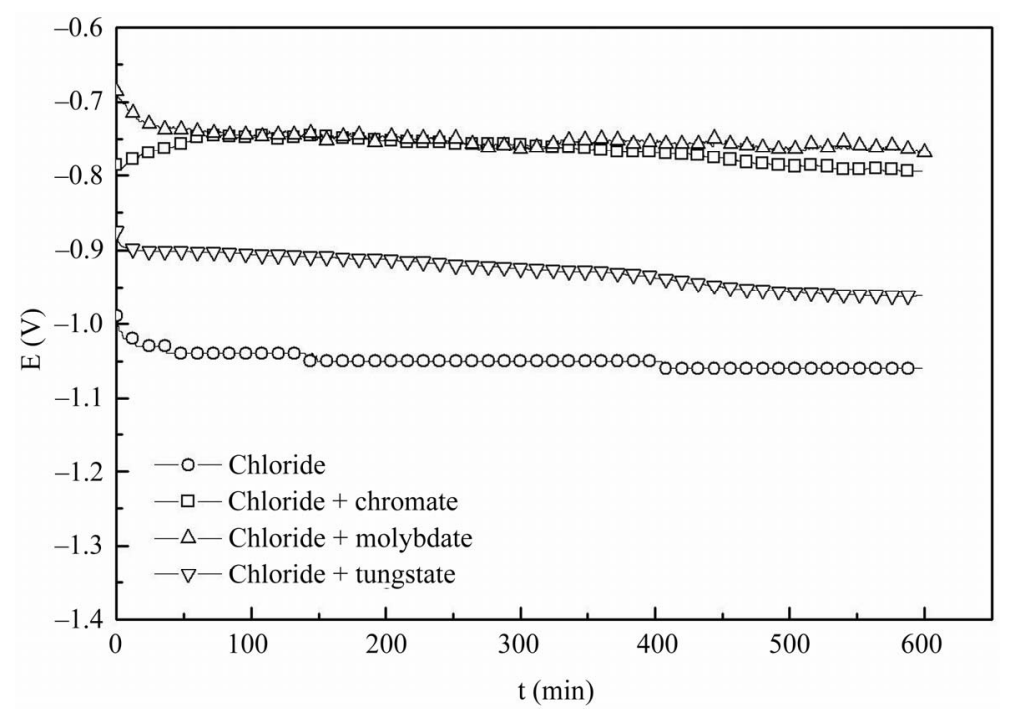

(a)

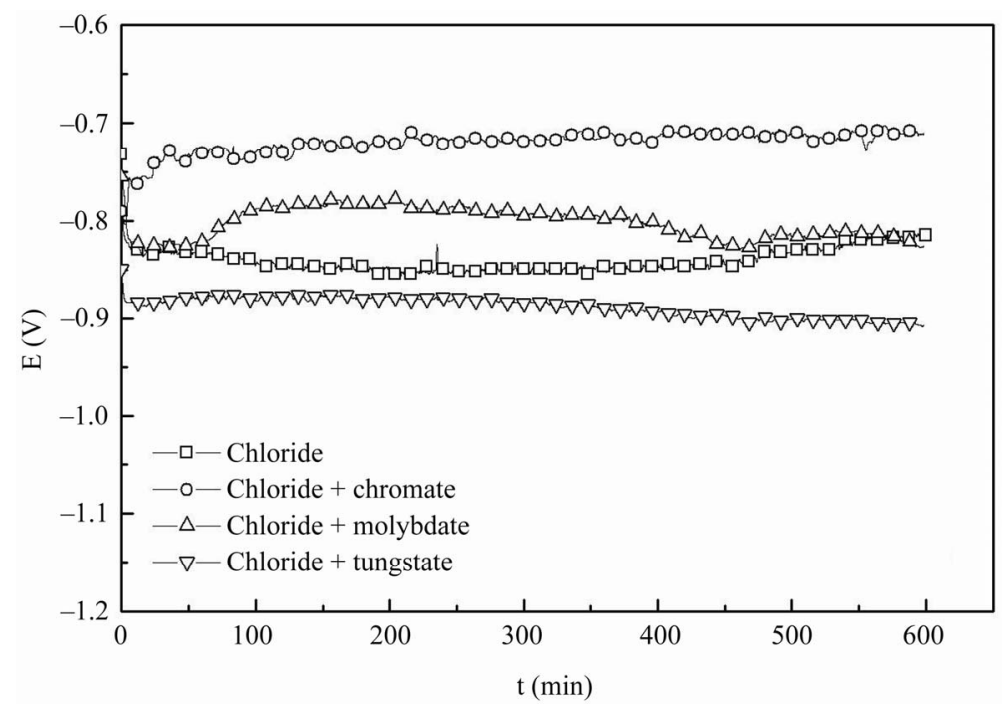

(b)

Figure 1. Open circuit potential curves in 3.5\% $\mathrm{NaCl}$ solution, $\mathrm{pH} 8.2$ and in presence of different oxy-anions $0.05 \mathrm{M}$, for electrodeposits: (a) Zn and (b) Zn-Fe-Co. 
product. In Figure 1(b), $\mathrm{CrO}_{4}^{2-}$ and $\mathrm{MoO}_{4}^{2-}$ ions caused a corrosion potential increase, indicating a positive effect of inhibitors on zinc alloy protection.

$\mathrm{WO}_{4}^{2-}$ addition in the solution shifted the alloy potential to more negative values, showing that it has not any inhibitory effect from corrosion to the alloy, which means a more active surface.

Factors, such as $\mathrm{pH}$ and oxygen presence, must be taken into account in the Fe-Zn-electrolyte system, because it has a very complex behavior. During corrosion, zinc alloy surface on steel in chloride solution, even in low concentration, shows $\mathrm{pH}$ variation. $\mathrm{pH}$ is high in remote areas of the layer, where the mechanism proposed to explain this increase results from the zinc oxidation process Equation (1) and from the reduction parallel reaction of the dissolved oxygen in aqueous medium Equation (2); oxygen is reduced by forming $\mathrm{OH}^{-}$ions, whereas Equation (3) is the predominant overall reaction. Next to the layer, $\mathrm{pH}$ becomes intermediate and in a region close to zinc layer it is low, being this decrease due to the metal hydrolysis reaction, where $\mathrm{H}^{+}$is simultaneously produced Equation (4).

$$
\begin{gathered}
\mathrm{Zn}_{(\mathrm{s})} \rightarrow \mathrm{Zn}^{2+}{ }_{(\text {aq })}+2 \mathrm{e}^{-} \\
\frac{1}{2} \mathrm{O}_{2(\mathrm{~g})}+\mathrm{H}_{2} \mathrm{O}_{(\mathrm{l})}+2 \mathrm{e}^{-} \rightarrow 2 \mathrm{OH}^{-}{ }_{(\mathrm{aq})} \\
2 \mathrm{Zn}_{(\mathrm{s})}+\mathrm{O}_{2(\mathrm{~g})}+2 \mathrm{H}_{2} \mathrm{O}_{(\mathrm{l})} \rightarrow 2 \mathrm{Zn}(\mathrm{OH})_{2(\mathrm{~s})} \\
\mathrm{Zn}^{2+}{ }_{(\text {aq })}+\mathrm{H}_{2} \mathrm{O}_{(\mathrm{l})} \rightarrow \mathrm{ZnOH}_{(\text {(aq })}^{+}+\mathrm{H}^{+}{ }_{(\mathrm{aq})}
\end{gathered}
$$

Just above the zinc layer, in region containing low $\mathrm{pH}$ value, a high $\mathrm{Zn}^{2+}$ concentration is developed. Conversely, in the most distant regions of zinc layer, $\mathrm{Zn}^{2+}$ does not exist. During corrosion, due to concentration gradients of $\mathrm{H}^{+}, \mathrm{OH}^{-}$and $\mathrm{Zn}^{2+}$, solutions are mixed, due to continuous $\mathrm{H}^{+}$production by releasing $\mathrm{Zn}^{2+}$. These are the processes that possibly occur both on zinc and alloy surface, besides the anodic process of dissolution on zinc surface by chloride and passivation caused by oxygen reduction Equations (5) and (6) [5].

$$
\begin{aligned}
& 5 \mathrm{Zn}^{2+}{ }_{(\mathrm{aq})}+\mathrm{H}_{2} \mathrm{O}_{(\mathrm{l})}+8 \mathrm{OH}^{-}{ }_{(\text {aq })}+2 \mathrm{Cl}^{-}(\text {aq) } \\
& \rightarrow \mathrm{Zn}_{5} \mathrm{Cl}_{2}(\mathrm{OH})_{8} \cdot \mathrm{H}_{2} \mathrm{O}_{(\mathrm{s})} \\
& \mathrm{Zn}^{2+}{ }_{(\mathrm{aq})}+\frac{1}{2} \mathrm{O}_{2(\mathrm{~g})}+2 \mathrm{e}^{-} \rightarrow \mathrm{ZnO}_{(\mathrm{s})}
\end{aligned}
$$

Zinc, in oxy-anions presence, has characteristic behaviors of anodic inhibitors, favoring a direct formation of metal oxides and oxides coming right from reduction of its own inhibitor. The displacement of potential for more positive values is result of oxides stability formed in a slightly alkaline solution. In solution containing chromate, the $\mathrm{ZnO}$ and $\mathrm{Cr}_{2} \mathrm{O}_{3}$ formation can be consid- ered as a result of corrosion inhibiting effect on zinc, according to Equation (7). Similarly, in molybdate presence, Equation (8), there is formation of $\mathrm{ZnO}$ and $\mathrm{MoO}_{2}$ or $\mathrm{MoO}_{3}$ [6].

$$
\begin{gathered}
3 \mathrm{Zn}+2 \mathrm{CrO}_{4}^{2-}+2 \mathrm{H}_{2} \mathrm{O} \rightarrow 3 \mathrm{ZnO}+\mathrm{Cr}_{2} \mathrm{O}_{3}+4 \mathrm{OH}^{-} \\
\mathrm{Zn}+\mathrm{MoO}_{4}^{2-}+\mathrm{H}_{2} \mathrm{O} \rightarrow \mathrm{ZnO}+\mathrm{MoO}_{2}+2 \mathrm{OH}^{-}
\end{gathered}
$$

The oxy-anions tungstate and molybdate are very effective corrosion inhibitors in localized corrosion inhibition of steels their alloys in media containing chloride. The tungstate action way is similar to oxy-anion molybdate. Tungsten can form a large number of complex and, in slightly acidic solutions, they form insoluble oxides such as $\mathrm{WO}_{2}, \mathrm{~W}_{2} \mathrm{O}_{5}$ and $\mathrm{WO}_{3}$. In presence of alkaline solutions, they have a slight tendency to decompose water, releasing hydrogen, being dissolved in hexavalent state as tungstate ions $\left(\mathrm{WO}_{4}^{2-}\right)$. The $\mathrm{WO}_{4}^{2-}$ anion has properties similar to a buffer, consuming $\mathrm{H}^{+}$ions, which are produced in hydrolysis of metal cations Equation (9) suppressing the local acidification. In addition, polymeric species of tungstate are formed with metal cations, Equation 10, and can be adsorbed on metal surface, repairing defects and pits, producing a stable passive layer [7].

$$
\begin{aligned}
& \mathrm{WO}_{4}^{-2}+\mathrm{H}^{+} \square \quad \mathrm{HWO}_{4}^{-} \\
& \mathrm{HWO}_{4}^{-}+\mathrm{H}^{+}+2 \mathrm{H}_{2} \mathrm{O} \square \quad \mathrm{W}(\mathrm{OH})_{6}
\end{aligned}
$$

\subsection{Potentiodynamic Polarization Curves}

From electrochemical studies, potentiodynamic polarization curves were carried out with electrodeposits of $\mathrm{Zn}$ and $\mathrm{Zn}-\mathrm{Fe}$-Co before and after the blue chromatization, at a scan rate of about $0.333 \mathrm{mV} \cdot \mathrm{s}^{-1}\left(20 \mathrm{mV} \cdot \mathrm{min}^{-1}\right)$, starting in a $-0.30 \mathrm{~V}$ potential below the corrosion potential. In Figure 2, curves were obtained in aerated solution of $3.5 \% \mathrm{NaCl}, \mathrm{pH} 8.2$ and it was observed in cathodic region both for the electrogalvanised and the alloy, with and without passivation, a limit current which indicates a diffusional control, i.e., the procedure is controlled by the oxygen diffusion due to oxygen reduction reaction on metal.

For treatment-free samples, $\mathrm{Zn}$ and $\mathrm{Zn}$-Fe-Co showed current densities of about $1.8 \times 10^{-5} \mathrm{~A} \cdot \mathrm{cm}^{-2}$ and $2.5 \times$ $10^{-5} \mathrm{~A} \cdot \mathrm{cm}^{-2}$, respectively. After zinc chromatization, a clear change in cathodic region occurs, where initially a current decrease appears, attributed to the barrier effect carried out by $\mathrm{CrO}_{4}^{2-}$ layer [8] and also presence of limit current of oxygen reduction, which in this case is much lesser, of about $1.1 \times 10^{-6} \mathrm{~A} \cdot \mathrm{cm}^{-2}$. For the recorded curves, it is verified that chromatization effect does not affect corrosion potential, because for these coatings the potential value is approximately $-1.0 \mathrm{~V}$, that is, they remain constant. Therefore, it is noted that although chro- 
mate layer acts effectively in corrosion current density reduction, it has little effect on localized corrosion resistance.

After corrosion potential in anodic region, it is noticed an active zinc dissolution reaching a current density of about $20 \mathrm{~mA} \cdot \mathrm{cm}^{-2}$. For potential values close to $-0.4 \mathrm{~V}$, there is a current decrease, which is associated with zinc removal and consequent steel exposure; above this potential only substrate dissolution occurs.

Figure 3(a) shows that when oxy-anions are added to chloride solution, it is observed a change in reduction process mechanism, probably due to reduction of these anions on electrode [9]. These anions addition shifts the electrogalvanised corrosion potential and $\mathrm{Zn}-\mathrm{Fe}-\mathrm{Co}$ alloy to more positive values, indicating an increase on the localized corrosion resistance of metal in such media, also in all cases a cathodic current decrease occurs. Following results analysis, compared to other anions, chromate is the inhibitor that provides the most zinc protection. An analysis of corrosion potential values $\left(\mathrm{E}_{\text {corr }}\right)$ and corrosion current density $\left(\mathrm{j}_{\text {corr }}\right)$ also shows that chromate presents a better performance Table 1.

In aerate medium, the two samples have shown limit current of oxygen reduction and results have not revealed a passive behavior. When the systems were deaerated with nitrogen gas bubbling at room temperature of about $25^{\circ} \mathrm{C}$, the experiments conducted in $3.5 \% \mathrm{NaCl}$ exhibited, in cathodic region, a typical behavior of activation control and in anode region a slight passivation tendency for $\mathrm{Zn}$ and $\mathrm{Zn}-\mathrm{Fe}-\mathrm{Co}$ samples. Corrosion potentials obtained in aerated medium were approximately $-0.97 \mathrm{~V}$ and in deaerated medium $-1.17 \mathrm{~V}$, Figure 3(b).

\subsection{Cyclic Voltammetry}

At a speed of $33.3 \mathrm{mV} \cdot \mathrm{s}^{-1}$, the cyclic voltammetry tests have been carried out, starting a scan at $-1.5 \mathrm{~V}$ towards anodic potentials with potential reversal in region where material dissolution is observed.

Cyclic voltammograms for electrodeposits of $\mathrm{Zn}$ and $\mathrm{Zn}-\mathrm{Fe}-\mathrm{Co}$ are shown in Figure 4(a). Anodic process is characterized by presence of an oxidation current peak at about $-1.2 \mathrm{~V}$, attributed to an oxide film or zinc hydroxide formation on electrode. Then it is observed the metal dissolution, which occurs beginning at $-1.0 \mathrm{~V}$. In this potential region, it is possible to verify that zinc coating

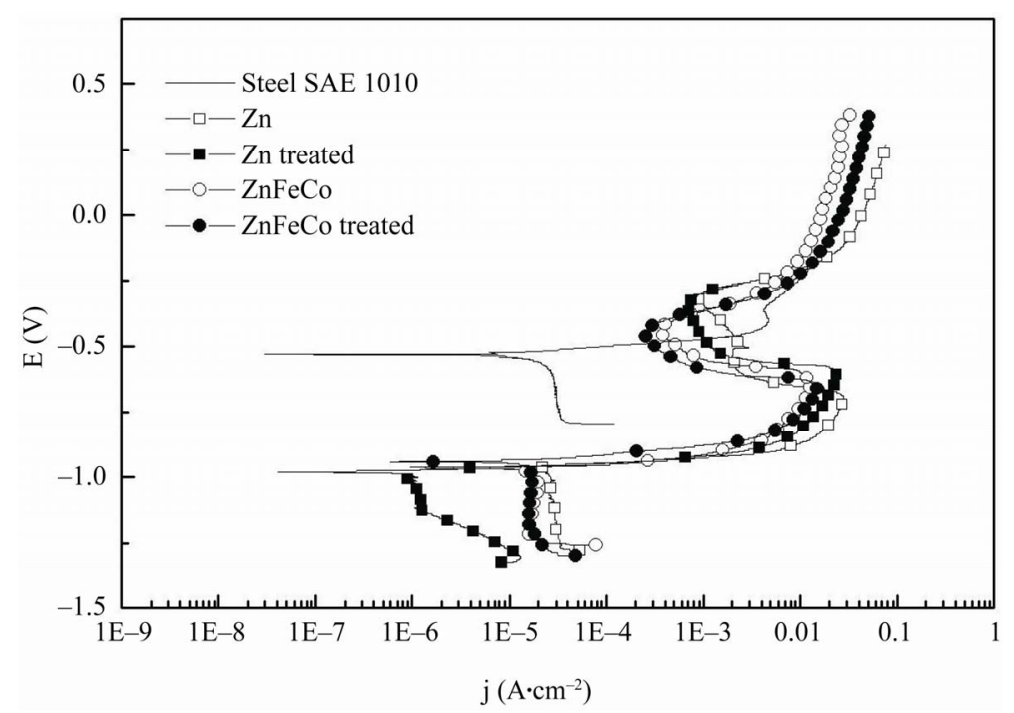

Figure 2. Potentiodynamic polarization curves in $3.5 \% \mathrm{NaCl}, \mathrm{pH} \mathrm{8.2,} \mathrm{for} \mathrm{steel} \mathrm{and} \mathrm{electrodeposits} \mathrm{with} \mathrm{and} \mathrm{without} \mathrm{treat-}$ ment.

Table 1. Corrosion potential values $\left(E_{\text {corr }}\right)$ and corrosion current density $\left(j_{\text {corr }}\right)$ for pure $\mathrm{Zn}$ and $\mathrm{Zn}-\mathrm{Fe}-\mathrm{Co}$, in $3.5 \% \mathrm{NaCl}$ solution and with addition of $\mathrm{CrO}_{4}^{2-}, \mathrm{MoO}_{4}^{2-}$ or $\mathrm{WO}_{4}^{2-} \mathrm{0.05} \mathrm{M}$.

\begin{tabular}{ccccc}
\hline $\mathrm{Zn}$ & $\mathrm{NaCl}$ & $\mathrm{NaCl}+$ chromate & $\mathrm{NaCl}+$ molybdate & $\mathrm{NaCl}+$ tungstate \\
\hline $\mathrm{E}_{\mathrm{corr}} / \mathrm{V}$ & -0.97 & -0.70 & -0.76 & -0.94 \\
$\mathrm{j}_{\text {corr }} / \mathrm{A} \cdot \mathrm{cm}^{-2}$ & $2.8 \times 10^{-5}$ & $5.8 \times 10^{-7}$ & $3.6 \times 10^{-6}$ & $2.8 \times 10^{-6}$ \\
\hline $\mathrm{Zn}-\mathrm{Fe}-\mathrm{Co}$ & $\mathrm{NaCl}$ & $\mathrm{NaCl}+$ chromate & $\mathrm{NaCl}+$ molybdate & $\mathrm{NaCl}+$ tungstate \\
\hline $\mathrm{E}_{\text {corr }} / \mathrm{V}$ & -0.94 & -0.69 & -0.63 & -0.77 \\
$\mathrm{j}_{\text {corr }} / \mathrm{A} \cdot \mathrm{cm}^{-2}$ & $2.4 \times 10^{-5}$ & $6.6 \times 10^{-7}$ & $5.4 \times 10^{-6}$ & $6.9 \times 10^{-6}$ \\
\hline
\end{tabular}




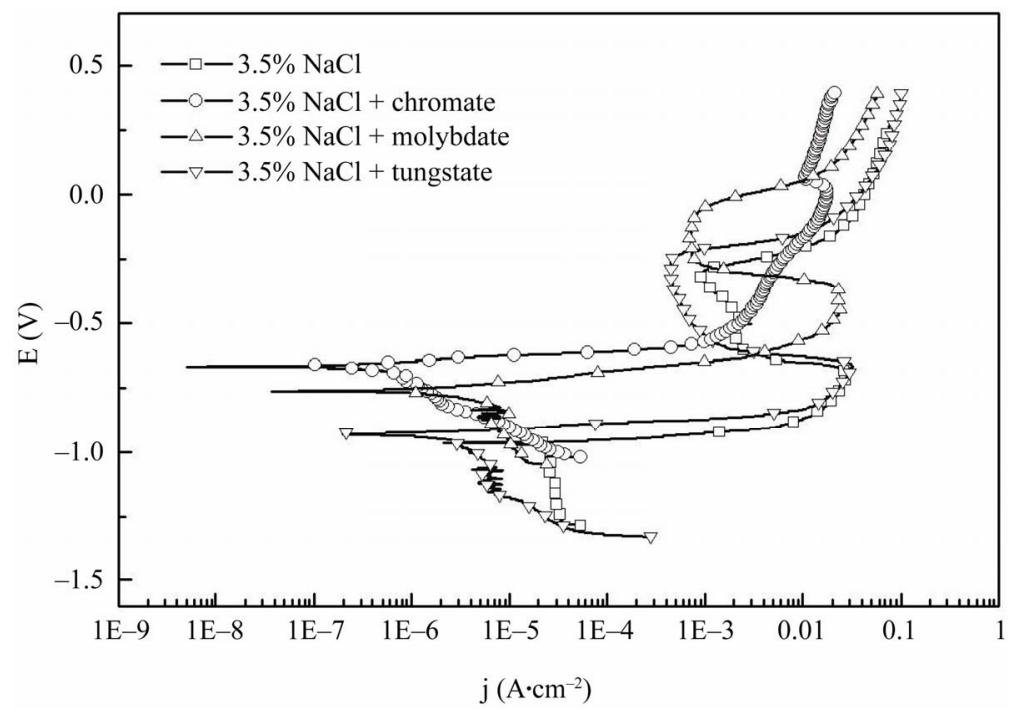

(a)

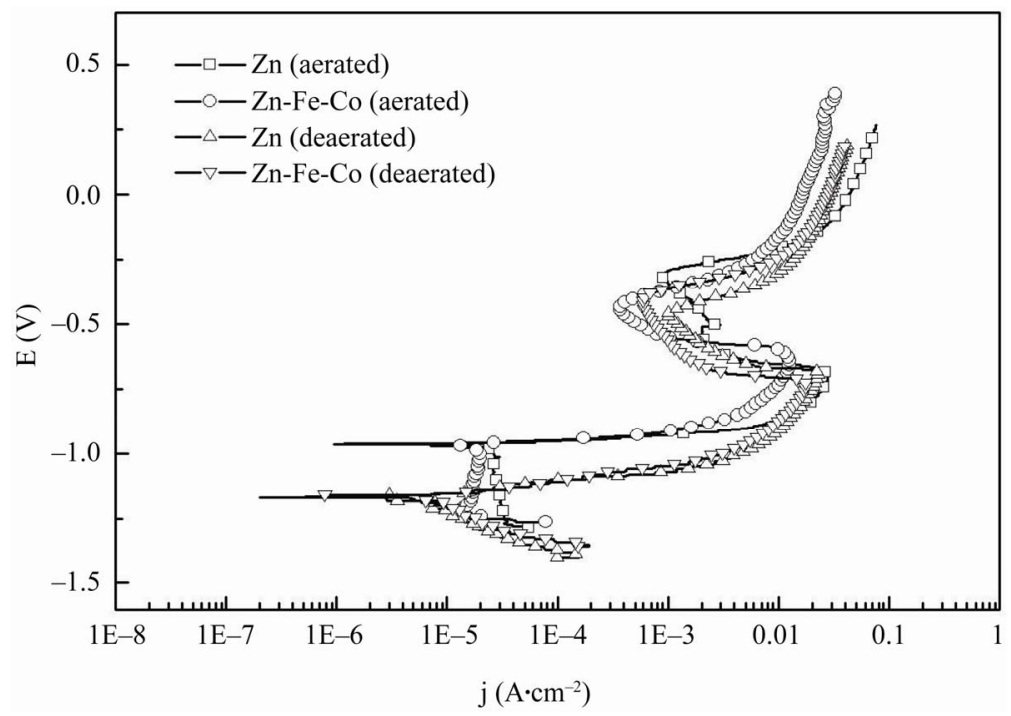

(b)

Figure 3. Potentiodynamic polarization curves for electrodeposits: (a) Pure $\mathrm{Zn}$ in a $3.5 \% \mathrm{NaCl}$ solution, pH 8.2; and in chloride with addition of $\mathrm{CrO}_{4}^{2-}, \mathrm{MoO}_{4}^{2-}$ or $\mathrm{WO}_{4}^{2-} \mathbf{0 . 0 5} \mathrm{mol} \cdot \mathrm{L}^{-1}$; (b) For $\mathrm{Zn}$ and $\mathrm{Zn}-\mathrm{Fe}-\mathrm{Co}$ in aerated and deaerated chloride solution.

has less stability than the Zn-Fe-Co electrodeposit, whose dissolution occurs at more anodic potentials. After the potential scan inversion, it is observed, towards negative potentials, a reduction current peak localized at $-1.37 \mathrm{~V}$, associated with reduction of the film formed in oxidation process. This reduction process becomes more complex and its load increases when the anodic reversal potential reaches higher values, where the present concentration of soluble zinc species becomes elevated. For chromatized electrodeposits Figure 4(b), it is observed that occurs a significant charge reduction and this is related to oxidation and reduction processes in zinc oxide/hydroxide formation region, which indicates the efficiency of the applied process.

\section{Conclusions}

From the electrochemical tests carried out, it can be concluded that the steel subjected to electrodeposition process and then to chromatization treatment has shown to be more corrosion resistant than the passivation-free electrodeposits. The corrosion potential remained almost unchanged, whereas a significant decrease at corrosion current density has occurred for the pure $\mathrm{Zn}$ treated sample. The steel substrate exhibits a corrosion potential of approximately $-0.5 \mathrm{~V}$, which shows a big difference among the electrodeposits potentials in study indicating that they protect steel by acting as a sacrificial metal.

By adding oxy-anions to $3.5 \% \mathrm{NaCl}$ solution it has 


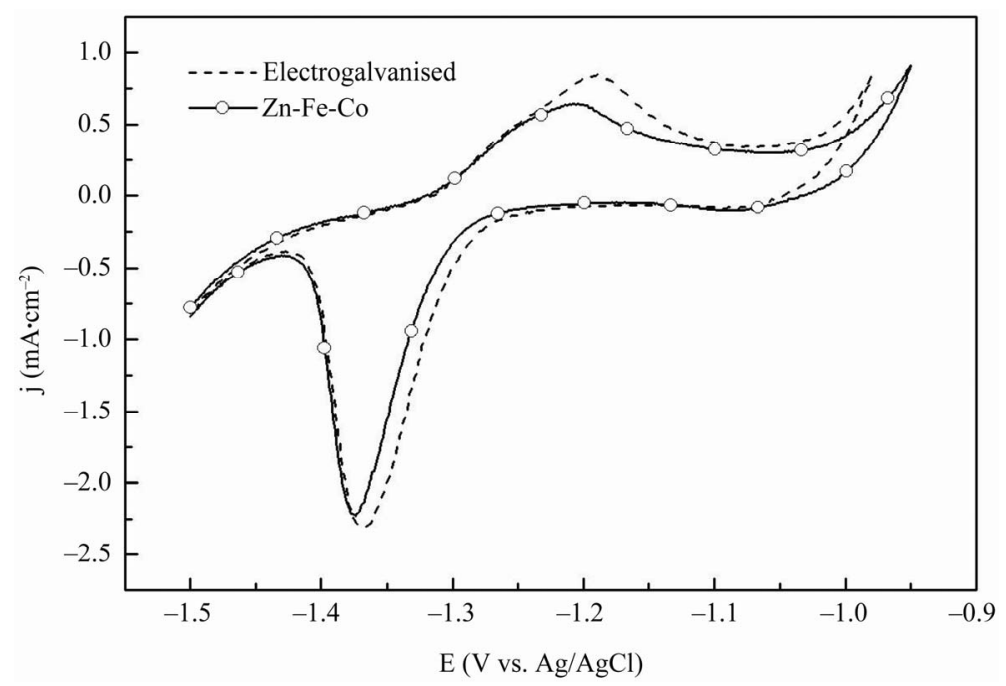

(a)

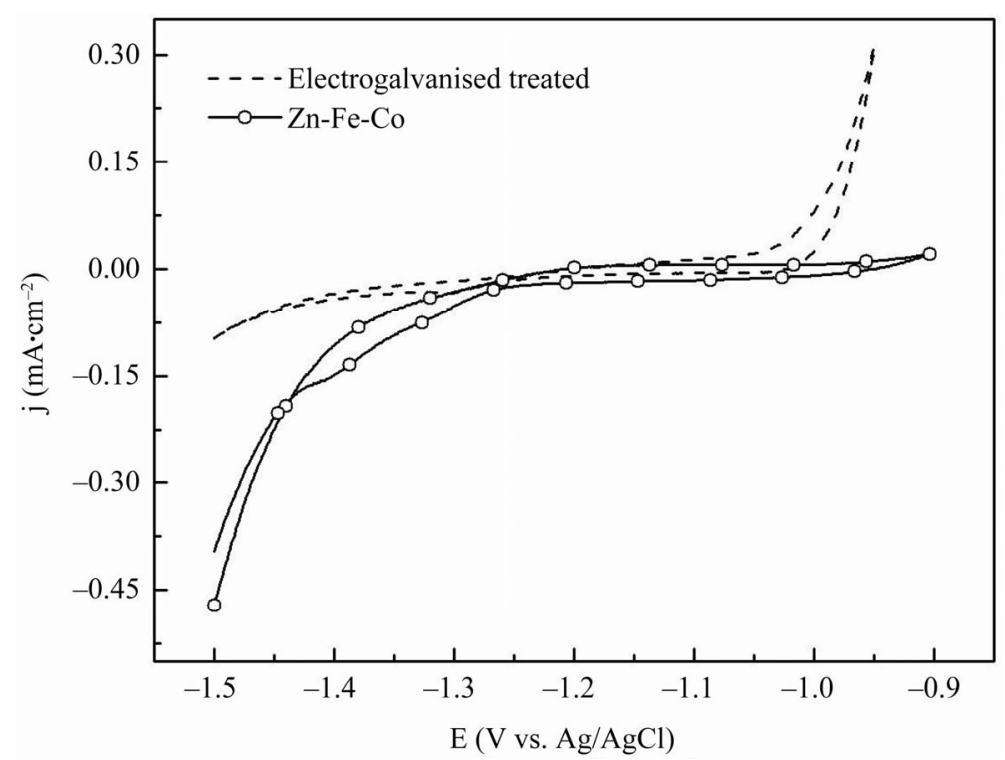

(b)

Figure 4. Cyclic voltammograms for electrodeposits of $\mathrm{Zn}$ and $\mathrm{Zn}-\mathrm{Fe}-\mathrm{Co}$ on steel in 3.5\% NaCl solution, pH 8.2: (a) without treatment and (b) with treatment.

resulted in a significant reduction of corrosion current density, and in a displacement of corrosion potential to more noble values.

Both for $\mathrm{Zn}$ and $\mathrm{Zn}-\mathrm{Fe}-\mathrm{Co}$, deaerating $\mathrm{NaCl}$ solution has resulted in the elimination of limit current of oxygen reduction, indicating a mechanism change of the cathodic process.

\section{Acknowledgements}

Authors thank to COOKSON ELECTRONICS BRAZIL LTDA and FUNDUNESP (process 01258/08-DFP).

\section{REFERENCES}

[1] R. Favaron and L. M. Aleixo, "Voltammetric Determina- tion of Zn (II) in Zn-Fe Alloy Electroplating Baths Using Square-Wave Voltammetry," Journal of the Brazilian Chemical Society, Vol. 12, No. 2, 2001, pp. 173-179. doi:10.1590/S0103-50532001000200008

[2] A. Brenner, "Electrodeposition of Alloys," Academic Press, New York, 1963.

[3] P. L. Neto, A. O. Souza, M. I. C. Nogueira and R. P. Colares, "Estudos da Corrosão de Eletrodepósitos de Zn-Ni, Zn-Fe e Zn-Co em meio de Cloreto e de Sulfato," Coteq, Salvador, 2002.

[4] Z. Wu, L. Fedrizzi and P. L. Bonora, "Electrochemical Studies of Zinc-Nickel Codeposition in Chloride Baths," Surface and Coatings Technology, Vol. 85, No. 3, 1996, pp. 170-174. doi:10.1016/0257-8972(96)02857-5

[5] E. Tada, S. Satoh and H. Kaneko, "The Spatial Distribu- 
tion of $\mathrm{Zn}^{2+}$ during Galvanic Corrosion of a $\mathrm{Zn} /$ steel Couple," Electrochimica Acta, Vol. 49, No. 14, 2004, pp. 2279- 2285. doi:10.1016/i.electacta.2004.01.008

[6] C. B. Breslin, G. Treacy and W. M. Carrol, "Studies on the Passivation of Aluminium in Chromate and Molybdate Solutions," Corrosion Science, Vol. 36, No. 7, 1994, pp. 1143-1154. doi:10.1016/0010-938X(94)90139-2

[7] D. S. Azambuja, E. M. A. Martini and I. L. Muller, "Corrosion Behaviour of Iron and AISI 304 Stainless Steel in Tungstate Aqueous Solutions Containing Chloride," Journal of the Brazilian Chemical Society, Vol. 14, No. 4,
2003, pp. 570-576.

doi:10.1590/S0103-50532003000400013

[8] R. Fratesi and G. Roventi, "Corrosion Resistance of ZnNi Alloy Coatings in Industrial Prodution," Surface and Coatings Technology, Vol. 82, No. 1-2, 1996, pp. 158164. doi:10.1016/0257-8972(95)02668-1

[9] G. D. Wilcox and D. R. Gabe, "Passivation Studies Using Group VIA Anions. Part 5: Cathodic Treatment of Zinc," Britsh Corrosion Journal, Vol. 22, No. 4, 1987, pp. 254258. 